Article

\title{
Browning of Early and Late-Harvested 'Empire' Apples Affected by Cold Storage and 1-MCP
}

\author{
Seok-Kyu Jung and Hyun-Sug Choi * \\ Department of Horticulture, Daegu Catholic University, Gyeongsan-si, Gyeongbuk 38430, Korea; \\ gentleman71@msn.com \\ * Correspondence: hchoiuark@gmail.com
}

Received: 22 June 2020; Accepted: 20 July 2020; Published: 21 July 2020

\begin{abstract}
The effects of harvest time, 1-methylcyclopropene (1-MCP) and air storage time on the susceptibility of flesh browning in 'Empire' apples were studied during a seven-day shelf life period after air storage at $0.5{ }^{\circ} \mathrm{C}$ for seven months. Early- or late-harvested 'Empire' apples without 1-MCP increased production of ethylene, respiration rates and internal ethylene concentration during the shelf life. Respiration rates increased in the late-harvested fruit for the shelf life period with/without 1-MCP treatment. The 1-MCP-treated fruit was approximately $10 \mathrm{~N}$ firmer than fruit not treated with $1-\mathrm{MCP}$ at an early harvest for the entire shelf life duration. Peroxidase activity and percent change in electrical conductivity in the flesh were elevated in late-harvested fruit for the shelf life duration, whereas polyphenol oxidase activities were found to be stimulated by 1-MCP treatment, regardless of harvest time. Late-harvested fruit treated with 1-MCP exhibited increased susceptibility to flesh browning during shelf life, mostly due to reduction of the antioxidant defense mechanism of the fruits to stress in extending storage life, increasing polyphenol oxidase (PPO) activity and electrolyte leakage rate.
\end{abstract}

Keywords: Malus $\times$ domestica; 1-MCP; browning disorder; polyphenol oxidase; peroxidase

\section{Introduction}

Internal flesh browning of 'Empire' apples (Malus sylvestris (L.) Mill Var. domestica Borkh.) is a physiological disorder known to occur intermittently during long-term storage that considerably reduces the postharvest quality of the fruit and renders it unacceptable in the market [1-5]. Biochemical browning in apples mostly results from the oxidation of phenolic compounds to o-quinones by polyphenol oxidase (PPO) leading to brown discoloration and synergistically reacting with peroxidase (POX) activity [5-8]. The oxidation of phenolic compounds in apple flesh is dependent upon numerous factors including a fruit's nutritional status, flesh structure, the geographic location of orchards, irrigation systems, seasonal variability, tree age, harvest time, 1-MCP (1-methylcyclopropene) treatment, $\mathrm{CO}_{2}$ and $\mathrm{O}_{2}$ levels, storage temperature and duration and adoption or non-adoption of CA (controlled atmosphere) storage with low temperatures $[9,10]$. Therefore, understanding the relationship between phenolic enzyme activity and the factors affecting phenolic oxidation in 'Empire' apples during storage is important to control the risk of disorder development.

$1-\mathrm{MCP}$ is extensively used in the agricultural industry to maintain storage potential and quality in horticultural crops as an ethylene action inhibitor during long-term storage [11,12]. The benefit of 1-MCP for apples is extended shelf life of the fruits, while a disadvantage is unpredictable fruit browning in long-term storage. The 1-MCP and dynamic CA applications promoted internal browning in 'Elstar' apples due to $\mathrm{CO}_{2}$ injury caused by high storage temperature [13]. PPO (peroxidase) or POX (polyphenol oxidase) antioxidants in controlled atmosphere-stored 'Empire' apples increased with 1-MCP treatment likely due to extended duration of fruit sensitivity to stress and lower energy 
levels, inducing the development of flesh browning [1,4,14]. There is little information available to date regarding the susceptibility of apples air-stored conventionally in developing countries. 'Empire' is particularly susceptible to browning on exposure to low $\mathrm{O}_{2}$ and high $\mathrm{CO}_{2}$ levels in the atmosphere $[1,2,4,5]$, but the fruit's resistance to browning in air and CA is largely dependent upon harvest time [3].

A late harvest increased incidences of flesh browning in CA-stored 'Braeburn' apples $[9,15,16]$ and air-stored 'Macoun' apples [17] due to an observed increase in respiration rates, skin resistance to gas transport and internal $\mathrm{CO}_{2}$ concentrations, causing $\mathrm{CO}_{2}$ injury and low $\mathrm{O}_{2}$ damage, which was not consistently observed for a core browning in air-stored 'Empire' apples [3]. Flesh browning in 'Empire' apples at early and late harvest does not develop until after six months of air-storage and its effect on shelf life has not been evaluated with regards to distribution time. Late-harvested 'McIntosh' apples with multiple 1-MCP treatments showed increased incidences of browning, which did not similarly occur on the treated 'Empire' fruit [18]. No information is yet available about the interaction between 1-MCP and storage time at harvest time. The aim of this research was to investigate the effects of harvest times, treatment of fruits with 1-MCP and length of time in air storage, all of which are the primary concerns of fruit storage management, on the susceptibility of flesh browning in 'Empire' apples exposed to room temperature after long-term cold storage.

\section{Materials and Methods}

\subsection{Plant Material and Sampling}

'Empire' apples (Malus sylvestris (L.) Mill Var. domestica Borkh.) at early and late stages of maturity were, respectively harvested once from mature trees grown at the Cornell University orchard located at Ithaca, USA. Early stages of fruit maturity indicated internal ethylene concentrations of less than $30 \mu \mathrm{L} \mathrm{L}^{-1}$ or greater for later stages of maturity, with a one-month interval between both maturities. 'Empire' apples from early and late stages of maturity were harvested from different locations on the trees in a season. Half of the sample of 600 'Empire' apples were treated with or without $1 \mu \mathrm{L} \mathrm{L}{ }^{-1}$ of 1-MCP after $1 \mathrm{~d}$ of overnight cooling. The 1-MCP treatments were applied following the method of Watkins et al. [19] using an activator solution added with SmartFresh tablets (AgroFresh, Philadelphia, PA, USA) released into a $4000 \mathrm{~L}$ plastic tent. After venting for $3 \mathrm{~h}$ and overnight cooling, 600 -fruit were stored at low temperature $\left(0.5^{\circ} \mathrm{C}\right)$.

At each sampling point, five individual fruits from each treatment were sampled to analyze ethylene production, respiration rates, internal ethylene concentration (IEC) and flesh firmness at 0,1 , 3, 5 and 7 days shelf life after the 7-month storage period. After measuring IEC of each fruit, fruit flesh tissue was immediately put into liquid nitrogen and then stored at $-80^{\circ} \mathrm{C}$ to analyze peroxidase (PPO), polyphenol oxidase (PPO) and total phenolic concentrations.

Incidence of the disorder was visually assessed by the extent of flesh browning at each sampling point, expressed on a scale of $0=0 \%$ (no browning), $1=1-10 \%$ (slight browning), $2=11-25 \%$, $3=26-75 \%$ and $4=76-100 \%$ (almost complete browning) from the cut surface of the flesh tissue.

\subsection{Ethylene Production and Respiration}

Each fruit was sealed in a $1 \mathrm{~L}$ plastic container for $1 \mathrm{~h}$ to analyze ethylene production, fruit respiration rate and IEC (internal ethylene concentration). One $\mathrm{mL}$ of gas from the plastic containers was used to measure the concentration of ethylene and IEC, using a Hewlett-Packard 5890 series II gas chromatograph (Hewlett-Packard Co., Wilmington, NC, USA) equipped with a flame ionization detector and an activated alumina SS column (Supelco, Philadelphia, PA, USA). Respiration rates were also measured by a Varian 3499 gas chromatograph (Series 580; Varian, Bridgewater, MA, USA) using gas from each sample. 
Flesh firmness was measured on the opposite poles of each fruit using an EPT-1 pressure tester (Lake City Technical products, Lake City, AB, Canada) with an 11-mm-diameter probe, after the skin was thinly removed.

\subsection{Enzyme Extraction and Assays}

For each enzyme extraction, $3 \mathrm{~g}$ of flesh tissue sample was ground to fine powder in liquid nitrogen and put into $9 \mathrm{~mL}$ of extraction $200 \mathrm{mM}$ phosphate buffer (pH 7.8) containing $2 \mathrm{mM}$ of ethylenediaminetetraacetic acid (EDTA), 5\% polyvinylpolypyrrolidone (PVPP) and $1 \mathrm{mM}$ phenylmethanesulfonyl fluoride (PMSF). The mixture was then homogenized and centrifuged at $14,000 \times \mathrm{g}$ for $30 \mathrm{~min}$ at $4{ }^{\circ} \mathrm{C}$. The supernatant was divided into aliquots and kept at $-80{ }^{\circ} \mathrm{C}$ to assay the enzymes and proteins.

POX and PPO activities were spectrophotometrically measured following the methods of Kochhar et al. [20] and Zhou et al. [21], respectively. In order to measure the activities of POX and PPO, $200 \mu \mathrm{L}$ of extraction was added to each $2.8 \mathrm{~mL}$ assay solution, separately. The assay solution of POX was a $100 \mathrm{mM}$ phosphate buffer ( $\mathrm{pH}$ 6.8) containing $2.7 \mathrm{mM}$ guaiacol and $4 \mathrm{mM} \mathrm{H}_{2} \mathrm{O}_{2}$. The assay solution of PPO was a $100 \mathrm{mM}$ citrate-200 mM phosphate buffer (pH 5.0) containing $50 \mathrm{mM}$ catechol. The activities of POX and PPO were assessed through changes in optical density (OD) at 470 and $420 \mathrm{~nm} \mathrm{mg}^{-1} \mathrm{of}^{\circ}$ protein, respectively using a spectrophotometer (Beckman-Counter, DU 7400, Fullerton, CA, USA) [21]. Protein concentration was determined via the method of Bradford (1976) using bovine serum albumin as standard [22].

\subsection{Total Phenolic Concentration}

Ten $g$ of frozen tissue from each fruit was extracted with $80 \%$ acetone to determine total phenolic concentrations, using a modified Folin-Ciocâlteu colorimetric method [4,23]. The absorbance was measured with a spectrophotometer (Beckman-Counter, DU 7400, Fullerton, CA, USA) and expressed as gallic acid equivalents based on fresh weight.

\subsection{Leakage Assessment}

Electric leakage was determined by measuring mesocarp tissue samples from apples stored at $0.5^{\circ} \mathrm{C}$ in air storage for up to 7 months and evaluated for $7 \mathrm{~d}$ at $20^{\circ} \mathrm{C}$, which were then cut into discs with a cork borer ( $2 \mathrm{~mm}$-thick and $12 \mathrm{~mm}$ in diameter) using a modified method by Barrett et al. [24]. Discs were washed with distilled water 3 times, incubated in $0.4 \mathrm{M}$ mannitol for $30 \mathrm{~min}$ at $25^{\circ} \mathrm{C}$, autoclaved for $30 \mathrm{~min}$ at $121^{\circ} \mathrm{C}$ and cooled to $25^{\circ} \mathrm{C}$. The leakage was then measured using a conductivity meter (Chemtrix Type 700, Hillsboro, OR, USA) after $30 \mathrm{~min}$ and calculated from the presence of total electrolytes.

\subsection{Statistical Analysis}

All data were subjected to ANOVA using Minitab software v. 15.1 (Minitab, Inc., State College, PA, USA). Means were separated using least significant differences (LSD) at $p=0.05$. Data over time are shown as means \pm standard errors.

\section{Results}

Ethylene production in the early harvested 'Empire' apples not treated with 1-MCP gradually increased over $4 \mathrm{~d}$ of shelf life at $20^{\circ} \mathrm{C}$ after 7 -months of cold storage and started to decrease from 5 days to 7 days, with very low levels observed for $1 \mathrm{MCP}$-treated fruit (Figure 1A). Initial amounts of ethylene produced in the late-harvested fruit was $3.3 \mathrm{ng} \mathrm{kg} \mathrm{s}{ }^{-1}$ and $0.8 \mathrm{ng} \mathrm{kg} \mathrm{s}^{-1}$ for untreatedand 1-MCP-treated fruit, respectively, with continuously low levels observed for the $6 \mathrm{~d}$ of shelf life compared to the early harvested fruit (Figure 1B). The $1 \mathrm{MCP}$ treatment resulted in lower respiration 
rates in the early harvested fruit throughout a 7 days shelf-life (Figure 2A), but this effect was only slightly observed in late-harvested fruit. (Figure 2B).

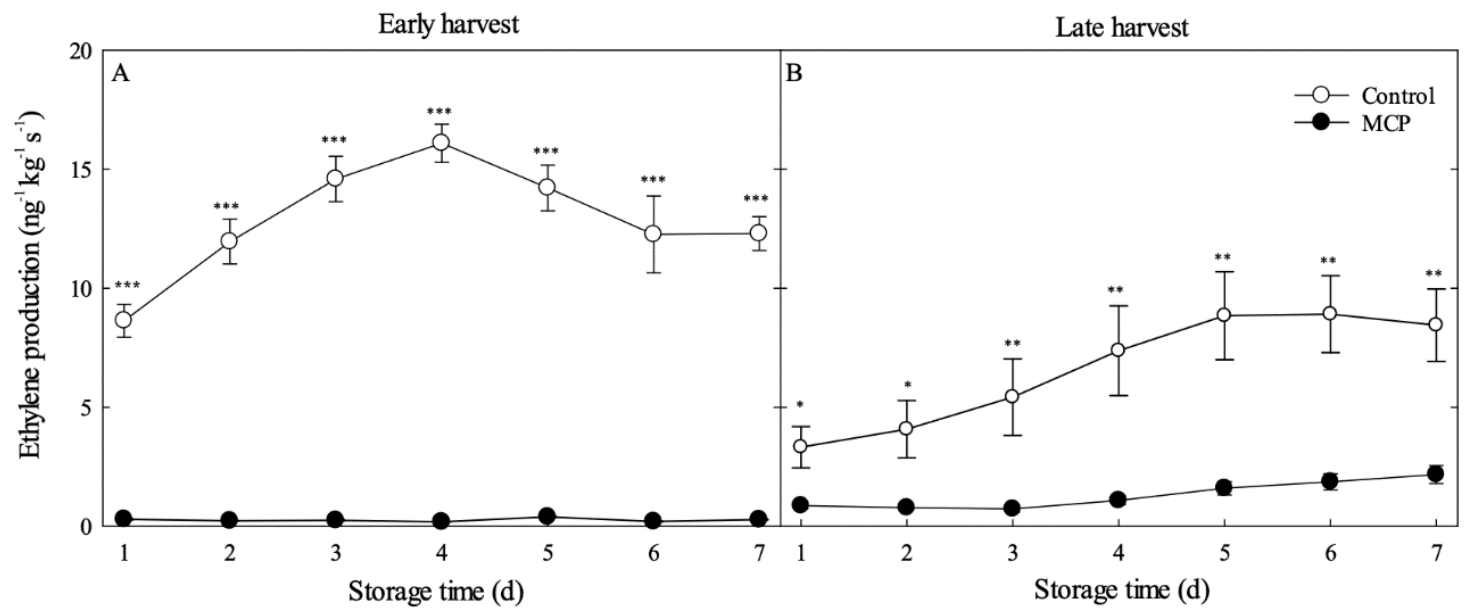

Figure 1. Ethylene production of early (A) and late-harvested 'Empire' apples (B) and stored at $0.5^{\circ} \mathrm{C}$ in air storage up to 7 months and evaluated for $7 \mathrm{~d}$ at $20^{\circ} \mathrm{C}$. Bars represent error of the means (SEM; $n=5$ ), when larger than the dimension of the symbol. *,**,*** Adjacent to each data point for each storage time indicates significant differences as determined by Duncan's multiple range test at $p \leq 0.05$, 0.01 or 0.001 , respectively. MCP-methylcyclopropene.

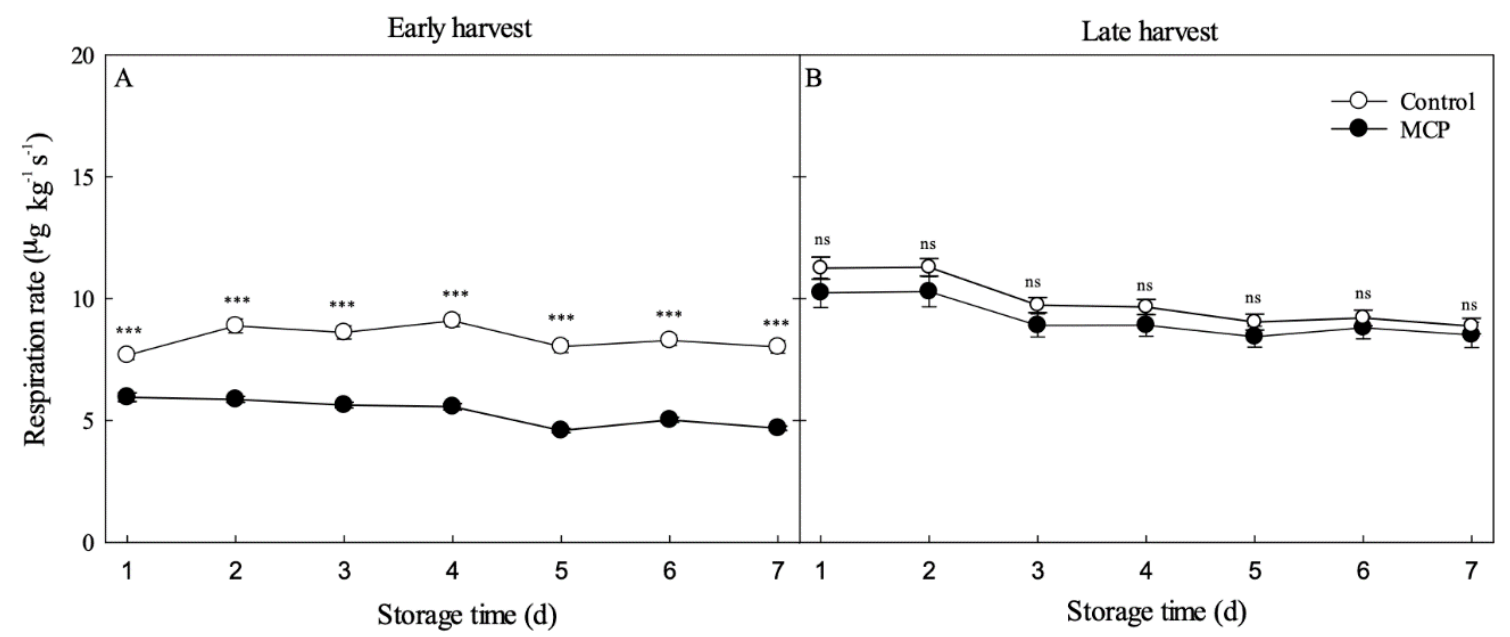

Figure 2. Respiration rate of early (A) and late-harvested 'Empire' apples (B) and stored at $0.5^{\circ} \mathrm{C}$ in air storage up to 7 months and evaluated for 7 days at $20^{\circ} \mathrm{C}$. Bars represent error of the means (SEM; $n=5$ ), when larger than the dimension of the symbol. ${ }^{* * *}$ Adjacent to each data point for each storage time indicates significant differences as determined by Duncan's multiple range test at $p \leq 0.001$; ns-not significantly different.

IEC (internal ethylene concentration) in the flesh ranged between 100-130 $\mu \mathrm{L} \mathrm{L}^{-1}$ for non-treated apples and less than $1.0 \mu \mathrm{L} \mathrm{L}^{-1}$ for 1-MCP-treated apples at an early harvest until the end of a 7 days shelf life period after 7 months of cold storage (Figure 3A). The highest IEC of $192.1 \mu \mathrm{L} \mathrm{L}^{-1}$ was observed at a 5 days shelf life for non-treated fruit, with $42.5 \mu \mathrm{L} \mathrm{L}^{-1}$ at 7 days for 1-MCP-treated fruit at a late harvest. The 1-MCP treatment increased approximately $10 \mathrm{~N}$ above average firmness at an early harvest during shelf life compared to the non-treated fruit but did not affect the firmness retention in a late harvest (Figure 3C,D). 


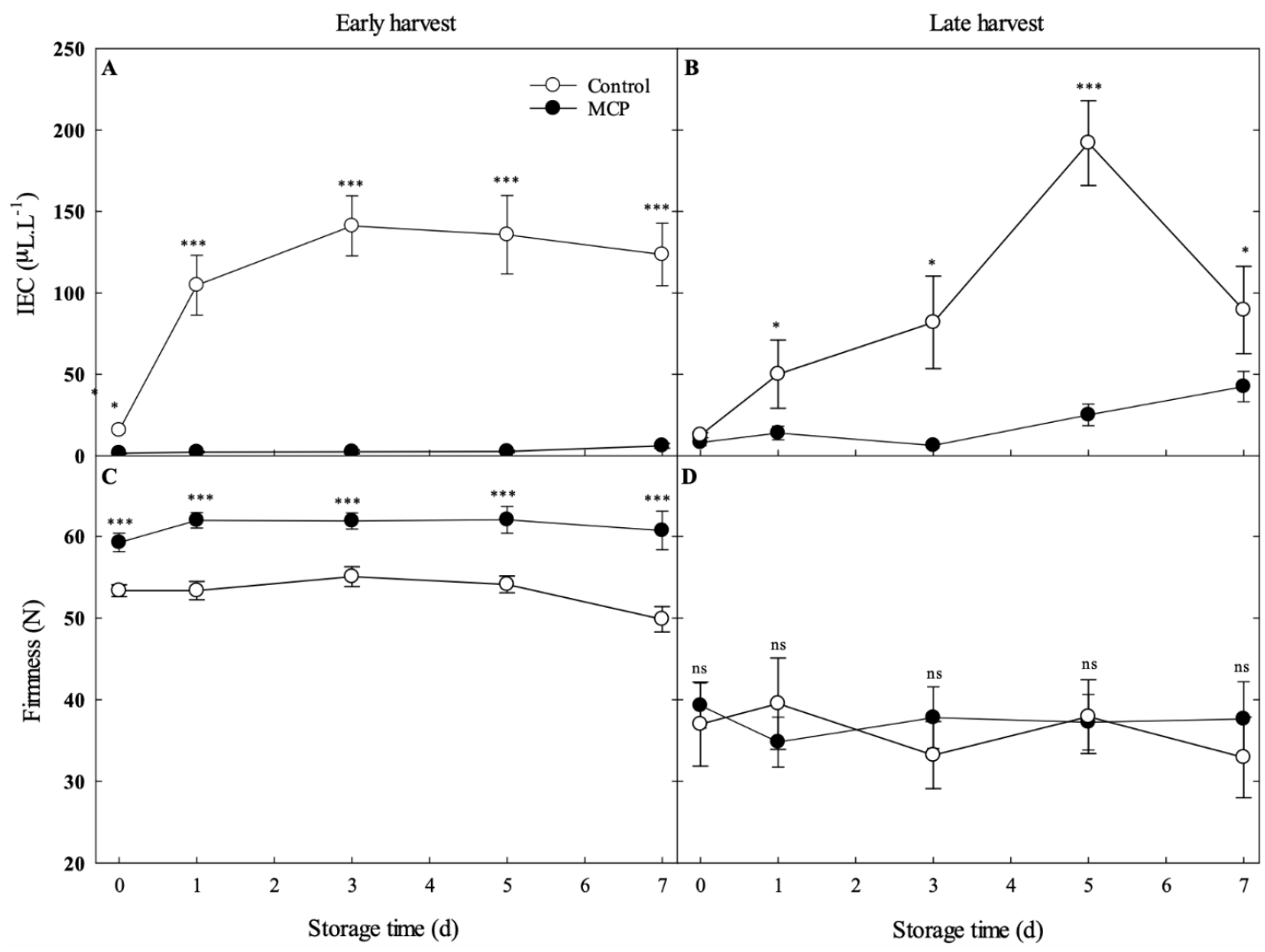

Figure 3. Internal ethylene concentration (IEC) (A,B) and flesh firmness (C,D) of early and late-harvested 'Empire' apples stored at $0.5^{\circ} \mathrm{C}$ in air storage up to 7 months and evaluated for 7 days. Bars represent error of the means (SEM; $n=5)$, when larger than the dimension of the symbol. ${ }^{*},{ }^{* * *}$ Adjacent to each data point for each storage time indicates significant differences as determined by Duncan's multiple range test at $p \leq 0.05$ and 0.001 , respectively; ns-not significantly different.

POX activities in the flesh were not affected by 1-MCP treatment at an early ( $p=0.757$; Figure 4A) and late harvest ( $p=0.117$; Figure 4B) but fluctuated at a late harvest. The 1-MCP treatment increased the flesh PPO activities at an early harvest $(p=0.001)$ and increased the flesh PPO activity in late-harvested fruit (Figure 4C,D). Total phenolic concentrations in the flesh were not affected by 1-MCP treatment in early harvested fruit but affected by 1-MCP treatment in late-harvested fruit after 1 day and 5 days at $20{ }^{\circ} \mathrm{C}$ (Figure 4E,F). A late harvest increased the risk of the development of browning, in particular for 1-MCP treated fruit (Figure $4 \mathrm{G}, \mathrm{H}$ ).

$\mathrm{CO}_{2}$ concentrations significantly influenced all the POX and PPO activities and total phenolic contents in the 1-MCP-treated fruit, with a correlation observed between $\mathrm{CO}_{2}$ and $\mathrm{POX}$ and PPO activities in the early harvested fruit (Table 1).

Table 1. Correlation between $\mathrm{CO}_{2}$ and POX, polyphenol oxidase (PPO) and total phenolic contents of early and late-harvested 'Empire' apples with/without $1-\mathrm{MCP}$ at $0.5^{\circ} \mathrm{C}$ in air storage up to 7 months and evaluated for 7 days at $20^{\circ} \mathrm{C}$.

\begin{tabular}{ccccccc}
\hline \multirow{2}{*}{ Variables } & \multicolumn{2}{c}{$\mathbf{C O}_{\mathbf{2}}$-POX } & \multicolumn{2}{c}{$\mathbf{C O}_{\mathbf{2}}$-PPO } & \multicolumn{2}{c}{$\mathbf{C O}_{\mathbf{2}}$-Phenol } \\
\cline { 2 - 7 } & $\mathbf{R}^{\mathbf{2}}$ & $\boldsymbol{p}$-Value & $\mathbf{R}^{\mathbf{2}}$ & $\boldsymbol{p}$-Value & $\mathbf{R}^{\mathbf{2}}$ & $\boldsymbol{p}$-Value \\
\hline Early harvest & 0.6077 & 0.0078 & 0.7061 & 0.0023 & 0.0051 & 0.9920 \\
Late harvest & 0.0114 & 0.3627 & 0.0306 & 0.9754 & 0.0154 & 0.0103 \\
With MCP & 0.5440 & 0.0149 & 0.4277 & 0.0402 & 0.7753 & 0.0008 \\
Without 1-MCP & 0.3850 & 0.0556 & 0.0650 & 0.4771 & 0.5329 & 0.0165 \\
\hline
\end{tabular}




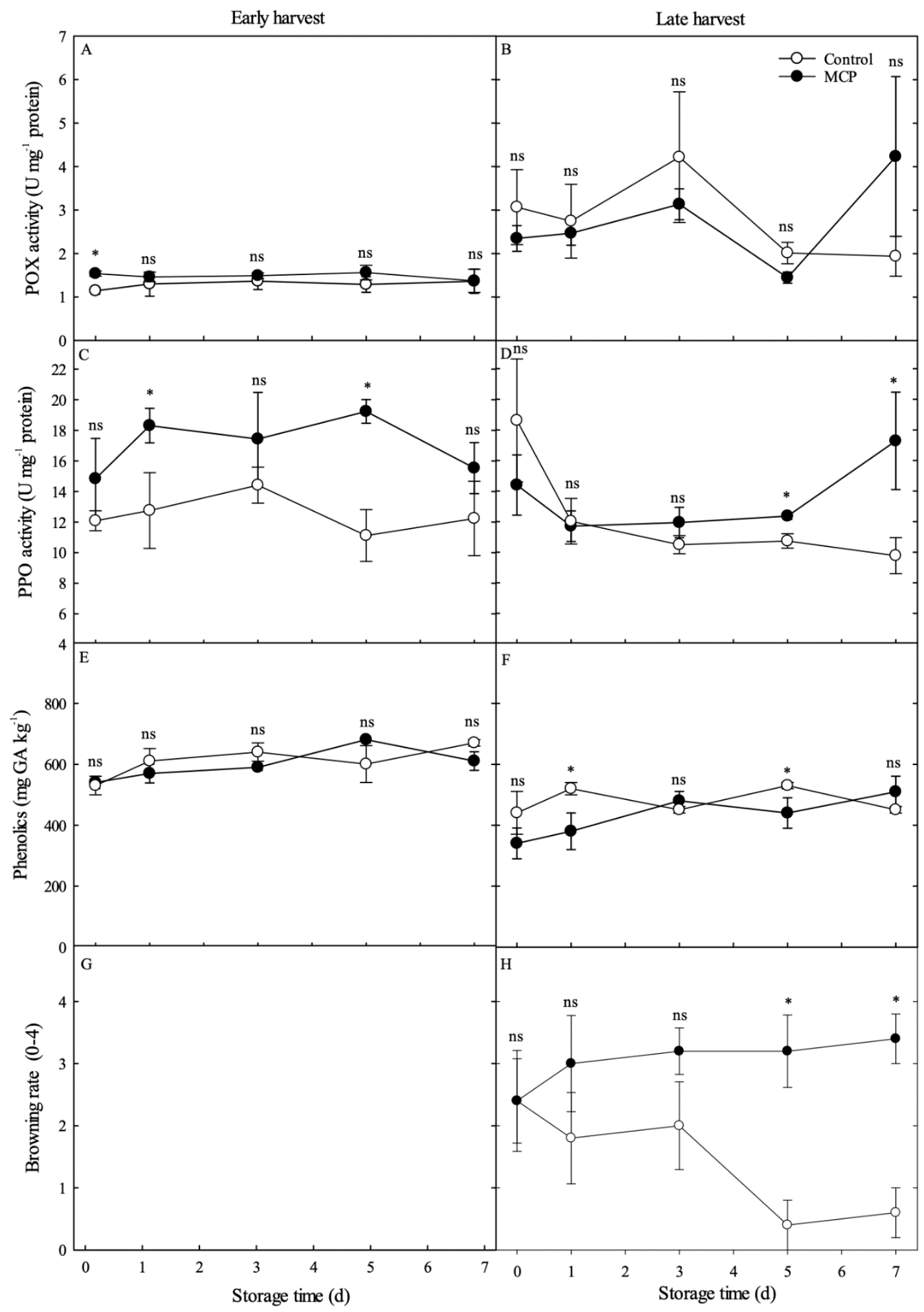

Figure 4. Peroxidase (POX) (A,B), PPO (C,D), total phenolic contents (E,F) and browning (G,H) of early and late-harvested 'Empire' apples and stored at $0.5^{\circ} \mathrm{C}$ in air storage up to 7 months and evaluated for 7 days at $20^{\circ} \mathrm{C}$. Bars represent error of the means (SEM; $n=5$ ), when larger than the dimension of the symbol. * Adjacent to each data point for each storage time indicates significant differences as determined by Duncan's multiple range test at $p \leq 0.05$; ns-not significantly different. 
Percent change in electrical conductivity of the flesh ranged from $40 \%$ to $60 \%$ at an early harvest (Figure 5A) and from 50\% to $80 \%$ at a late harvest (Figure 5B) for the duration of shelf life. The leakage was found to be slightly higher for fruit without 1-MCP at an early harvest and with 1-MCP at a late harvest after 7 days and 1 day at $20^{\circ} \mathrm{C}$, respectively.

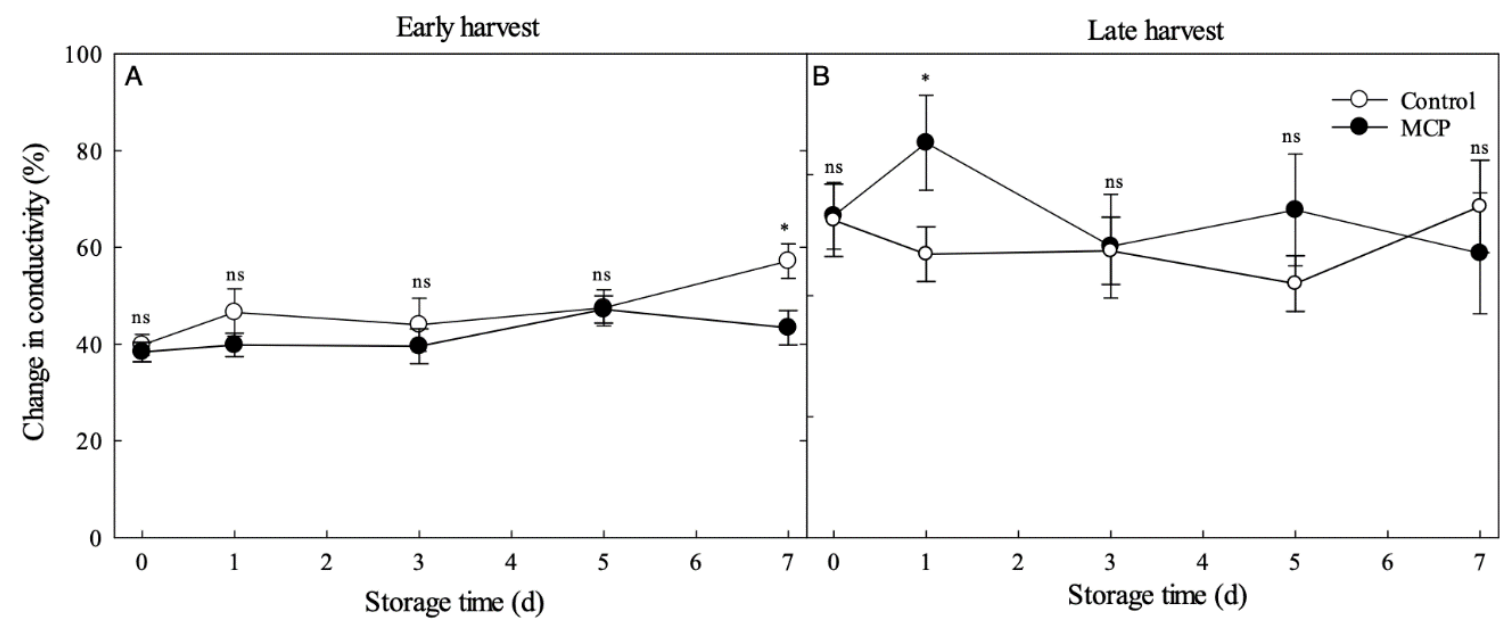

Figure 5. Leakage of early (A) and late-harvested 'Empire' apples (B) and stored at $0.5{ }^{\circ} \mathrm{C}$ in air storage up to 7 months and evaluated for 7 days at $20^{\circ} \mathrm{C}$. Bars represent error of the means (SEM; $n=5$ ), when larger than the dimension of the symbol. * Adjacent to each data point each storage time indicates significant differences as determined by Duncan's multiple range test at $p \leq 0.05$; ns-not significantly different.

\section{Discussion}

The 1-MCP treatment delayed IEC and maintained high fruit firmness in 'Empire' apples during the seven-month cold storage period plus 7 days shelf life duration. However, incidences of flesh browning in late-harvested fruit were increased by 1-MCP treatment, which was known to risk $\mathrm{CO}_{2}$ injury observed as internal browning in 'Elstar', 'Jonagold', 'Gloster', 'Empire' and 'Braeburn' apples $[1,4,9,13]$ and as skin browning in 'Granny Smith' and 'Golden Delicious' [25,26]. Blocking the pathway of ethylene signaling in the 1-MCP-treated apples would have resulted in an extended period of insensitivity to ethylene and exposure to oxidative stress [1]. This may be associated with progressive loss of fluidity of the plasma membrane, cell wall modification and increase of skin resistance to gas diffusion, resulting in high $\mathrm{CO}_{2}$ and low $\mathrm{O}_{2}$-related stress [1,10,13,15,27-29]. Simultaneously, impermeable cell membranes altered energy levels of fruit metabolism, reduced the functioning of cellular membranes and facilitated the release of PPO activity, eventually leading to browning, which was shown in higher leakage in the late-harvested fruit treated with 1-MCP in this study.

The optimum window for harvest was very closely connected with susceptibility to flesh browning over time, which was dramatically alleviated from late-harvested 'Empire' apples stored at an air temperature of $0.5^{\circ} \mathrm{C}$ in this study and at CA in the previous reports [3,30]. The 1-MCP-treatment of fruit may have resulted in higher tolerance of oxidative stress associated with concentrations of ethylene and free radical damage to proteins [8]. In our study, POX compound was found to increase in late-harvested fruit more sharply and would not be 1-MCP treatment dependent or at least not at this stage of fruit storage time. In addition, PPO activities increased in the late-harvested fruit treated with 1-MCP. Simultaneously, 'Empire' apples during the ripening period presumably experienced a decrease of gas diffusion rates across the cortical tissues of the fruit, signaling an initial symptom of browning, although the fruit density was lower than those of 'Braeburn', 'Fuji', 'Gala' and 'Red Delicious' apples [15].

Higher levels of phenolic compounds observed in the 1-MCP-treated fruit or late-harvested fruit may be associated with changes from the oxidizing enzymes of PPO and POX [4,13,31,32], which were 
not found to affect the relationship between the compounds in this study. Interestingly, increased $\mathrm{CO}_{2}$ concentrations in fruits treated with 1-MCP may be an important factor influencing the expression of POX and PPO in the flesh. Although 1-MCP treatment decreased $\mathrm{CO}_{2}$ concentrations, the risk of $\mathrm{CO}_{2}$ injury was increased in 'Elstar', 'Jonagold', 'Gloster' and 'Empire' apples [1,4,13]. Therefore, a strong reduction of concentrations of $\mathrm{CO}_{2}$ could compensate for the negative effects of 1-MCP.

Daily variations incidences of browning during the seven-day shelf life were not likely linked with POX or PPO daily trends. Consequently, a slight increase in the susceptibility to browning was only identified with high PPO in the late-harvested fruit treated with 1-MCP, regardless of storage time. Browning incidence was primarily observed in the 'Empire' apples stored in CA with improper concentrations of $\mathrm{O}_{2}$ or $\mathrm{CO}_{2}[33,34]$. This modified gas concentration in the fruit could be associated with a late harvest, increasing the percent change in electrical conductivity and disorder of the fruit treated with 1-MCP. Interestingly, fruit without 1-MCP treatment showed decreased browning rates for seven-day shelf life after a late harvest, which may be partially explained by the different sites on the tree used for fruit sampling as the fruits were hardly observed for browning symptoms in the higher branches.

\section{Conclusions}

There is little information about the 1-MCP mode of action under prolonged air-storage and shelf life simulation, affecting development of flesh browning in late-harvested 'Empire' apples. The 1-MCP treatment reduced the antioxidant defense mechanism of the fruits to stress in extending storage life, increasing PPO activity and electrolyte leakage rate. These factors could be evidently responsible for increasing browning symptoms of 1-MCP-treated 'Empire' apples under air-storage period for more than seven months. Further work should focus on extending experimental designs to include various harvest periods of the fruit variety for multiple years to identify an initiating signal for the development of browning through monitoring POX and other antioxidant activities.

Author Contributions: Data curation, S.-K.J. and H.-S.C.; investigation, S.-K.J.; visualization, S.-K.J.; writing-original draft, H.-S.C. All authors have read and agreed to the published version of the manuscript.

Funding: This research was funded by Cornell University.

Acknowledgments: We greatly acknowledge funding for this project from the New York Apple Research and Development Program, AgroFresh, Inc. and the Cornell University Agricultural Experiment Station, federal formula funds, Project NE-1036, received from the Cooperative State Research, Education and Extension Service, U.S. Department of Agriculture.

Conflicts of Interest: The authors declare no conflicts of interest.

\section{References}

1. DeELL, J.R.; Lum, G.B. Effects of low oxygen and 1-methylcyclopropene on storage disorders of 'Empire' apples. HortScience 2017, 52, 1265-1270. [CrossRef]

2. Fawbush, F.; Nock, J.F.; Watkins, C.B. External carbon dioxide injury and 1-methylcyclopropene (1-MCP) in the 'Empire' apple. Postharvest Biol. Technol. 2008, 48, 92-98. [CrossRef]

3. James, H.; Nock, J.F.; Watkins, C.B. Internal browning in Empire apples in relation to harvest date. N. Y. Fruit Q. 2010, 18, 11-14.

4. Jung, S.-K.; Watkins, C.B. Involvement of ethylene in browning development of controlled atmosphere-stored 'Empire' apple fruit. Postharvest Biol. Technol. 2011, 59, 219-226. [CrossRef]

5. Watkins, C.B.; Liu, F.W. Temperature and carbon dioxide interactions on quality of controlled atmosphere-stored 'Empire' apples. HortScience 2010, 45, 1708-1712. [CrossRef]

6. De Castro, E.; Barrett, D.M.; Jobling, J.; Mitcham, E.J. Biochemical factors associated with a $\mathrm{CO}_{2}$-induced flesh browning disorder of Pink Lady apples. Postharvest Biol. Technol. 2008, 48, 182-191. [CrossRef]

7. Mellidou, I.; Buts, K.; Hatoum, D.; Ho, Q.T.; Johnston, J.W.; Watkins, C.B.; Schaffer, R.J.; Gapper, N.E.; Giovannoni, J.J.; Rudell, D.R.; et al. Transcriptomic events associated with internal browning of apple during postharvest storage. BMC Plant Biol. 2014, 14, 328-344. [CrossRef] 
8. Vilaplana, R.; Valentines, M.C.; Toivonen, P.; Larrigaudiere, C. Antioxidant potential and peroxidative state of 'Golden Smoothee' apples treated with 1-Methylcyclopropene. J. Am. Soc. Hortic. Sci. 2006, 131, 104-109. [CrossRef]

9. Hatoum, D.; Buts, K.; Hertog, M.L.A.T.M.; Geeraerd, A.H.; Schenk, A.; Vercammen, J.; Nicolai, B.M. Effects of pre- and postharvest factors on browning in Braeburn. HortScience 2014, 41, 19-26. [CrossRef]

10. James, H.J.; Jobling, J.J. Contrasting the structure and morphology of the radial and diffuse flesh browning disorders and CO2 injury of 'Cripps Pink' apples. Postharvest Biol. Technol. 2009, 53, 36-42. [CrossRef]

11. Sisler, E.C.; Serek, M. Inhibitors of ethylene responses in plants at the receptor level: Recent developments. Physiol. Plant. 1997, 100, 577-582. [CrossRef]

12. Watkins, C.B. Overview of 1-methylcyclopropene trials and uses for edible horticultural crops. HortScience 2008, 43, 86-94. [CrossRef]

13. Köpcke, D. 1-Methylcyclopropene (1-MCP) and dynamic controlled atmosphere (DCA) applications under elevated storage temperatures: Effects on fruit quality of 'Elstar', 'Jonagold' and 'Gloster' apple (Malus domestica Borkh.). Eur. J. Hortic. Sci. 2015, 80, 25-32. [CrossRef]

14. Lee, J.W.; Cheng, L.; Rudell, D.R.; Watkins, C.B. Antioxidant metabolism of 1-methylcyclopropene (1-MCP) treated 'Empire' apples during controlled atmosphere storage. Postharvest Biol. Technol. 2012, 65, 79-91. [CrossRef]

15. Lau, O.L. Effect of growing season, harvest maturity, waxing, low $\mathrm{O}_{2}$ and elevated $\mathrm{CO}_{2}$ on flesh browning disorders in 'Braeburn' apples. Postharvest Biol. Technol. 1998, 14, 131-141. [CrossRef]

16. Wright, A.H.; Delong, J.M.; Arul, J.; Prange, R.K. The trend toward lower oxygen levels during apple (Malus $\times$ domestica Borkh) storage. J. Hortic. Sci. Biotechnol. 2015, 90, 1-13. [CrossRef]

17. Moran, R.E.; McManus, P. Firmness retention and prevention of coreline browning and senescence in. "Macoun" apples with 1-methylcyclopropene. HortScience 2005, 40, 161-163. [CrossRef]

18. DeEll, R.R.; Geoffrey, B.L.; Behrouz, E.M. Effects of multiple 1-methylcyclopropene treatments on apple fruit quality and disorders in controlled atmosphere storage. Postharvest Biol. Technol. 2016, 111, 93-98. [CrossRef]

19. Watkins, C.B.; Nock, J.F.; Whitaker, B.D. Responses of early, mid and late season apple cultivars to postharvest application of 1-methylcyclopropene (1-MCP) under air and controlled atmosphere storage conditions. Postharvest Biol. Technol. 2000, 19, 17-32. [CrossRef]

20. Kochhar, S.; Watkins, C.B.; Conklin, P.L.; Brown, S.K. A quantitative and qualitative analysis of antioxidant enzymes in relation to susceptibility of apples to superficial scald. J. Am. Soc. Hortic. Sci. 2003, 128, 910-916. [CrossRef]

21. Zhou, P.; Smith, N.L.; Lee, C.Y. Potential purification and some properties of Monroe apple peel polyphenol oxidase. J. Agric. Food Chem. 1993, 41, 532-536. [CrossRef]

22. Bradford, M.M. A rapid and sensitive method for the quantitation of microgram quantities of protein utilizing the principle of protein-dye binding. Anal. Biochem. 1976, 72, 248-254. [CrossRef]

23. Meyers, K.J.; Watkins, C.B.; Pritts, M.P.; Liu, R.H. Antioxidant and antiproliferative activities of strawberries. J. Agric. Food Chem. 2003, 51, 6887-6892. [CrossRef] [PubMed]

24. Barrett, D.M.; Lee, C.Y.; Liu, F.W. Changes in 'Delicious' apple browning and softening during controlled atmosphere storage. J. Food Qual. 1991, 14, 443-453. [CrossRef]

25. Zanella, A.; Cazzanelli, P.; Panarese, A.; Coser, M.; Chistè, C.; Zeni, F. Fruit fluorescence response to low oxygen stress: Modern storage technologies compared to 1-MCP treatment of apple. Acta Hort. 2005, 682, 1535-1542. [CrossRef]

26. Gamrasni, D.; Nerya, O.; Tsvilling, A.; Gizis, A.; Maoz-Katz, M.; Ben-Arie, R. Complexity of Preventing Diffuse Skin Browning (DSB) on 1-MCP (SmartFresh)-Treated ‘Golden Delicious' Apple. Acta Hort. 2009, $877,507-511$.

27. Bennett, A.B.; Labavitch, J.M. Ethylene and ripening-regulated expression and function of fruit cell wall modifying proteins. Plant Sci. 2008, 175, 130-136. [CrossRef]

28. Marangoni, A.G.; Palma, T.; Stanley, D.W. Membrane effects in postharvest physiology. Postharvest Biol. Technol. 1996, 7, 193-217. [CrossRef]

29. Schotsmans, W.; Verlinden, B.E.; Lammertyn, J.; Nicolai, B.M. The relationship between gas transport properties and the histology of apple. J. Sci. Food Agric. 2004, 84, 1131-1140. [CrossRef] 
30. Watkins, C.B.; Nock, J.F. Effects of delays between harvest and 1-methylcyclopropene treatment, and temperature during treatment, on ripening of air-stored and controlled-atmosphere-stored apples. HortScience 2005, 40, 2096-2101. [CrossRef]

31. Ding, C.K.; Chachin, K.; Hamauzu, Y.; Ueda, Y.; Imahori, Y. Effects of storage temperatures on physiology and quality of loquat fruit. Postharvest Biol. Technol. 1998, 14, 309-315. [CrossRef]

32. Qu, H.; Duan, X.; Su, X.; Liu, H.; Jiang, Y. Effects of anti-ethylene treatments on browning and energy metabolism of harvested litchi fruit. Aust. J. Exp. Agric. 2006, 46, 1085-1090. [CrossRef]

33. Hatoum, D.; Hertog, M.L.A.T.M.; Geeraerd, A.H.; Nicolai, B.M. Effect of browning related pre- and postharvest factors on the 'Braeburn' apple metabolome during CA storage. Postharvest Biol. Technol. 2016, 111, 106-116. [CrossRef]

34. Watkins, C.B.; Nock, J.F. Repeated treatment of apple fruit with 1-methylcyclopropene (1-MCP) prior to controlled atmosphere storage. Postharvest Biol. Technol. 2013, 79, 73-79.

(C) 2020 by the authors. Licensee MDPI, Basel, Switzerland. This article is an open access article distributed under the terms and conditions of the Creative Commons Attribution (CC BY) license (http://creativecommons.org/licenses/by/4.0/). 